
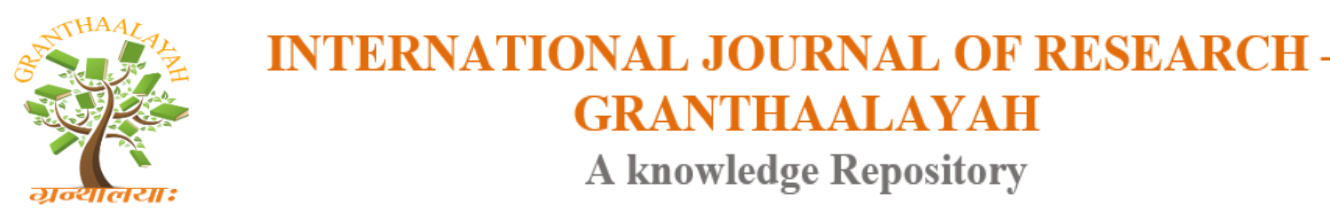

Social

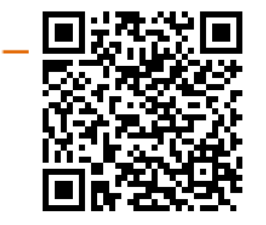

\title{
OJEBETA “THE SELF AWAKENED” IN BUCHI EMECHETA'S THE SLAVE GIRL
}

\author{
Mary Stella Rani B. ${ }^{1}$, Dr. Poli Reddy R. ${ }^{2}$ \\ ${ }^{1,2}$ Department of English, Acharya Nagarjuna University, Guntur, A.P, India
}

\begin{abstract}
The novel "The Slave Girl" by Buchi Emecheta exposes the plights of African women and portrayal of their struggle as slaves and ultimately how they come up the problem and becomes a self-awakened. In this paper, one can see Ojebeta starting her life as a slave and finally becomes an owner of a house by passing so many phases of life as a slave. In the beginning, she is sold into domestic slavery by her own brother. She has become the victim to her brother's traits. She has become a scapegoat to the plans of African patriarchy. The intention of Buchi Emecheta is to recreate the image of women through feminism. Emecheta's fiction is blended with reality representing socio historical elements of the prevailing society and its environment besides questioning the pathetic conditions of the people in general and women in particular. One can observe the narration of innocence of childhood grown into adulthood by attaining certain amount of freedom with the Christian education which she has received with which she has attained a small degree of self-awareness.
\end{abstract}

Keywords: Oppression; Fight for Freedom; Slavery; Inheritance of Women; Self-Awareness.

Cite This Article: Mary Stella Rani B., and Dr. Poli Reddy R.. (2018). "OJEBETA "THE SELF AWAKENED” IN BUCHI EMECHETA'S THE SLAVE GIRL." International Journal of Research - Granthaalayah, 6(10), 95-99. 10.29121/granthaalayah.v6.i10.2018.1166.

\section{Introduction}

Along with African men, women from Africa have been producing literature even though they received less notice from scholars and historians. Buchi Emecheta was to stay at home while her younger brother was sent to school. Later on her parents consider the benefits of her education. She passed her childhood at "All Girls Missionary School”.

All the works of Emecheta expose the plights of African women and portrayal of their struggle. The main characters of the novels exhibit how a mother and a woman in Nigerian society are. She completely rejects the ideas about women who are treated as symbol of sexual pleasures and a factory of production of children. She observes at how sexuality and to bear children be the only way to define feminity and womanhood. 
The Slave Girl (1977) describes the status of women who were denied of all opportunities and share the property of family in Nigerian Society. Ojebeta, the female protagonist of the novel, was a young girl. She was sold into domestic slavery by her brother. When her parents were passed away, there were none to look after her. Her parents' died of severe influenza epidemic and so all her rights were invested with her brother. Thus Ojebeta moved from her small village to a busy city. There she was converted to Christianity and they taught her to read and write. The author describes here the marriage system of those days. The institution of marriage is only a transfer of rights from one master to another one. Ojebeta married to a man who paid money to her owner thrown her into slavery again.

In The Slave Girl, it is the girl's companionship that makes life loveable for Ojebeta and it is by the encouragement of her peers like Chiago, Amanna and Nwanyinuzo that Ojebeta escapes from slavery. Every woman is a scapegoat in the plans of African patriarchy. Emecheta has no exception.

The exploitation and suppression of women in African society is the major themes of the writer. On the whole, one can notice that the position of women in African and even in Europe is very critical and completely non pessimistic. But there is a strong and stable place in Emecheta's novels for her feelings of African culture, tradition and respect to her sentiments on her motherland. These strong views made her a widely readable novelist of the age. Her fiction is blended with reality representing socio-historical elements of the prevailing society and its environment. Her language, style and diction are born out of reality questioning the pathetic conditions of the people in general and women in particular in the unrecorded atrocities of colonial rulers.

In the works of Emecheta, there is a clear picture of transformation of the African woman. Emecheta is the most prolific writer in West Africa today. She deals mainly with her own self-the Black African woman of Nigeria and her fortunes, before and after colonization and the social transformation.

In Slave Girl the protagonist Ojebeta, a young girl who is sold into slavery by her brother after her parents die, learns how to read and write being converted to Christianity, later marries to a man who pays of her owner and gets freedom from slavery from one man to another.

When Ojebeta, the adult, finally leaves Ma Palagadas' house asserts her freedom by choosing her own marriage partner, but realizes quickly, that in fact she has simply been granted the freedom to choose one master over another-Jerilyn Fisher. While Nwapa is the mother of Nigerian literature, second generation writer, Buchi Emecheta is identified as the symbol of African women's fight for freedom and was greatly inspired by the writings of Nwapa. She portrays a perplexed view of the divine material, most outstandingly in her fifth novel, critically deemed a culminating achievement in the literary career of BuchiEmecheta (Chineze Chukukera (1985). The model for Ojebeta, the main character of the Slave Girl is Emecheta's mother whom the author apostrophizes in her autobiography.

In this novel The Slave Girl, Emecheta illustrates the degradation and limitations of one's individualism and also the sexual exploitation concomitant with slavery. The novel "The Slave Girl" is sympathetic and honest, her style is clear and straightforward and her characterization, 
skillful. Ojebeta is a welcome addition to the still too small gallery of Nigerian heroines. (Anita Kern 1979).

The narrative of the Slave Girls depicts an ideal childhood. Emecheta creates a view of childhood as that stage in life where some freedom exists, freedom to be oneself, to be indulged, yet essentially a time that imparts the illusions that the future will continue as such. She did not know then that she too ".... Who had been encouraged to trust everybody, to say what she felt like saying, to shout when she felt like doing so, would start behaving like these girls who so reminded her of the wooden dolls in front of her chi shrine" (p. 87).

Ojebeta was one of the few Palagada girls lucky enough to be able to remember who her people were and to have been old enough to be able to recall the first love her parents had showered over her. Over the years such thoughts had magnified and grown right inside her head until that while time before she was sold now seemed completely golden in her mind's eye (p.132) (Erica Dillon, 1997).

She uses slavery to represent the position of women, particularly married women. She gives more importance to the nature of literal slavery, its economic and social contexts and the rationalizations of its practitioners.

In Emecheta's novel the female protagonist experiences momentary feelings of independence for example, when Ojebeta returns to Ibuza and when she marries Jacob but the main emphasis of the novel suggests that, for the Nigerian woman, freedom is ephemeral and independence from one master only leads to enslavement by another (BarnaliTahbildar, 97).

In Buchi Emecheta'sThe Slave Girl, childhood acts as a disillusioned, almost cynical, contrast to adult hood, yet this story, like Graham Swift's water land, also shows how destructive external forces and oppressive social situations make that stage of life unstable. The Slave Girl gives only a brief specific depiction of childhood, when Ojebeta is a young girl and both her parents alive, but this representation reverberates in Ojebeta's adult life.

The Slave Girl insists that change is not only inevitable but desirable by juxtaposing a special childhood against the rest of Ojebeta's life as a slave (whether in bondage or marriage). Ojebeta uses slavery to represent the position of women particularly married women.

Safety is the prevalent topic of The Slave Girl. As the novel progresses, one can observe how frightening and unsafe the world of the living is for Ojebeta who is decorated with cowries and silver bells to protect her from 'evil friends'. Her face was decorated with tattooes by her mother in order to save her from slavery. But ironically it is her own brother who sells her and the tattooes make her conspicuous as she tries to escape from slavery in the market place. Emecheta seems resigned to the fact that woman will always belong to a subordinate class. The novel The Slave Girl illustrates the position of women in so many ways, including commentaries on the inheritance of women by men, the similarity between slavery and marriage and the restrictions and expectations of women in mourning. 
The story of The Slave Girl is simple frame work but Emecheta has woven into a great deal of sociological detail. The back ground information is skillfully integrated and the story of the young girl makes fascinating reading. There is some subdued irony in the last sentence, which describes Ojebeta as changing masters. Emecheta always has been telling throughout the novel that woman is never free, she always belongs to others, be it a father, a brother or a social group. But Ojebeta attains a certain amount of freedom which is unavailable to others because of her particular circumstances as an orphan sold into slavery and because of the education she has received which has given her a small degree of self-awareness.

Slavery affects the slaveholder as well as the enslaved person. Emecheta looks at both sides of slavery. Throughout the novel, the slave owners Ma Palagada is portrayed as a good natured, matronly figure who becomes a surrogate mother to the Slave Girl Ojebeta, yet the privilege of slavery infests Ma's real daughters, blinding them to the humanity of others. Emecheta says of Ma Palagada's daughters: When Ojebeta attains her freedom, from Palagadas, these masters are simply replaced by another, her own husband. She finally concludes that the role of wife is very similar to that of slave, for the wife is obligated to "honour your husband, who is . . your head, your heart, your soul" (.173). Emecheta's portrayal of slavery is real both literally and figuratively. In The Slave Girl one can see the status of woman in the society. In traditional African Societies, she is perceived as being less than a man. Woman is naturally weak, naïve and negative. The novelist Emecheta raises three issues in this novel, Slavery, Marriage and Possession. She presents the African woman as a slave without identity, respect or dignity. At the end of the novel, Chiago is pregnant by Pa Palagada, when Ma Palagada dies, Chiago becomes the wife of Pa Palagada. The African woman toils, drudges, serves and marries to bear children for the man. She is deprived of her dignity and honour. She is owned, possessed and used. So the status of woman is that of a slave. Money was paid for Ojebeta by Ma Palagada and Jacob. When she comes to know that she was being paid money by her brother, she was "almost fainting with that kind of disappointment and sense of unfairness which is inexplicable"

Marriage is therefore for Ojebeta another form of slavery. Once she was under Ma Palagada but now she is under Jacob. Thus the novel shows that there is an inextricable link between slavery and marriage. Throughout her life, the African woman, belongs to somebody. When she is at home in her childhood she is owned by her people, when she grows up her people will find a husband for her who pays something for her. The husband who pays something for her automatically becomes her new master. Thus the status of the African woman is that she is permanently somebody's property. Whether she is at home with her family, whether she is sold into slavery or married to a man, she must belong to someone. Thus ultimately one can say that she has no identity or individuality of her own.

Mezu points out that "Tradition confers on men total power over all females, be they wives or daughters or sisters (Mezu 140).

\section{Conclusion}

The educated women are able to free themselves from the masculine yoke quickly because of the economic empowerment, education bestows on them. Eradication of the traditions and customs which tries to break the emancipation of women is the need of the hour. They should rise above 
themselves from the humiliating condition, should look forward to raise their status. Women should be allowed to fight and seek social position. Masking men to compromise is not enough to rate women's equality to men. Women should be made to exhibit good moral habits and also stand for what they need to meet the need of the hour.

\section{References}

[1] Anita Kern: "World Literature Today, Vol 153 No. 1. The three worlds of Luso phone Literature (Winter, 1979) published by Board of Regents of the University of Oklahoma).

[2] Barnali Tahbildar, "The Role of the Nigerian Woman in Emecheta's The Slave Girl, English 27, 1997.

[3] Chineze Chukukera, Gloria. The Joys of Motherhood Chineze Chukukera (185), Gender voices and choices: Redefining women in contemporary African fiction: Enugu: Fourth Dimension, 1995.

[4] Erica Dillon 99. "A passage into Antithetical Adulthood: Emecheta's The Slave Girl”, English 27, 1997.

[5] Mezu, Rose Ure. "Buchi Emecheta “ “ The Bride Price " and " The Slave Girl”. A Shizonalytic Perspective. Ariel. A review of International English Literature, 28.1(1991).

*Corresponding author.

E-mail address: jabili.indian@ gmail.com 